\title{
Accountability: State Capacity in Upholding the Rights of Indigenous Peoples in Malaysia
}

\author{
Rohaida Nordin ${ }^{1 *}$ \\ ${ }^{1}$ Faculty of Law, University Kebangsaan Malaysia 43600 UKM Bangi, Selangor, Malaysia
}

\begin{abstract}
There is no proper mechanism for monitoring the effectiveness of indigenous legislation and evaluating its application in the day-to-day practice of the public administration and society. This paper firstly identifies and conceptualises the variables of State capacity and, secondly, provides empirical advances that analyse State capacity under each variable to demonstrate in practicing how those variables influence or determine the actual enjoyment of the indigenous peoples' rights in Malaysia. Toward the purposes of this analysis and from the literature review [14,45], this analysis has identified the following variables: (i) accountability; (ii) legal legitimacy; (iii) political will; and (iv) capacity building and resources. This paper however will focus on the first variable: State accountability. The analysis clearly illustrates the implementation gap in the public administration. In few exceptions, State bureaucracy reacts as a State capitalist or rent-seizing State towards new legislation or policy passed in favour of indigenous peoples and, in doing so, rejects the recognition of the indigenous peoples' rights.
\end{abstract}

\section{State capacity: analysis of the implementation gap}

State capacity is impossible to define because States are not unitary or monolithic structures, but organizational complexes. The primary interest of the present analysis is transformative capacity, whereby the emphasis is placed on State abilities to promote human rights. This paper will demonstrate how State capacity influences the implementation of human rights treaties, the existing of national legislations, and the policies on the indigenous peoples' rights in Malaysia. The present paper argues that State capacity, which has been shaped by the essential premises which lack of accountability, legitimacy, political will, and capacity building and resources, is a major factor that influences the implementation of the law and will eventually determine the actual enjoyment of the rights by the indigenous peoples. This analysis will support the argument on domestication of indigenous peoples' rights and demonstrate that the ability of the Malaysian State to discharge its responsibilities in the area of human rights effectively depends on the strength of its domestic institutions $[32,33]$.

*Corresponding author : rohaidanordin@ukm.my 
Despite legislative measures and judicial recognition, an implementation gap still exists between legislation and day-to-day reality in Malaysia. This paper highlights the obstacles and problems faced during the full implementation of legislative and administrative advances, moreover it may provide guidance for States that are committed to more effective implementation of existing legislation on the rights of the indigenous peoples.

\section{Accountability and rent-seizing state}

In carrying out its functions as administrator, policy maker and regulator, the capitalist State has often intervened in economic development [45]. In practice, by controlling and regulating the market [26] and undertaking production [49], Malaysia has a mixture of both methods of State intervention [7, 22, 42] in economic development, namely: (i) the controlling State; and (ii) the producing State (30). These structural attributes and environmental conditions enable a State to pursue a collection of self-serving revenue-maximizing State goals rather than collective goals (30). The State becomes dominated by vote-maximizing politicians [15] whose interventions generate rents [9] that private agents seek to capture [45]. The State as an instrument is actually in the hands of the ruling class, which in its day-to-day activities is involved in economic exploitation and political domination as well as ultimately leads to the emergence of political-economic elites in Malaysia [23,24]. A rent-seizing State is a product of a State that is lacking of accountability. Colin Scott defines accountability as "the ability to give account for one's actions to some other persons or body" [36]. Broadly speaking, the fulfilment of accountability generally involves ex-post oversight of the action of one person or institution by another person or institution. Normanton offers a more expansive definition: a liability to reveal, explain and justify what one does; how one discharges responsibilities, financial or other, whose several origins may be political, constitutional, hierarchical or contractual [8]. Lack of accountability therefore facilitates the creation of a rent-seizing State where the State is not liable to reveal, explain and justify its actions and responsibilities.

O'Connor notes that a capitalist State must accomplish two basics, yet contradictory, functions: accumulation and legitimisation [34]. As a result, the State must create a conducive environment for capitalist accumulation and generate conditions for social harmony. A capitalist State that openly uses coercion enables one class to accumulate capital at the expense of other classes risks losing its legitimacy and undermining the basis of its loyalty and support. O'Connor's principles can be used against the Bumiputra policy in Malaysia that serves the interests of a few major indigenous groups. These dominant indigenous groups reactions to the policies are normally considered while amending the existing policy or making the new economic policy. The Bumiputrapolicy, however, undermines Malaysia's legitimacy with the non-Bumiputra.Malaysia can be seen as an institution trying to reconcile conflicting ethnic interests (between different ethnic groups) that exist as a product of historical development.

\subsection{State-owned enterprise}

State-owned enterprise (SOE) is one of the manifestations of State intervention in the economics of a producing State, assigned with the responsibility of fulfilling specific social goals, including correcting regional and economic imbalances, providing employment and reducing the concentration of monopoly power in the economy [16,30]. State intervention in economics through SOE is, however, not the same as the oligarchic State introduced by Likosky 29[5]. Unlike SOE, where the State becomes the participant or player in the market, 
Likosky's State oligarchy intervenes indirectly when its oligarchs (State officials) collaborate selectively with private people in ways that influence the economy in favour of the interests of such public officials and/or private persons [29]. Depending on the nature of the intervention, the SOE can be categorised as a producing State and the State oligarchy as a controlling State.

Also assessing the Malaysian SOE's performance, one can adopt either property rights theory or public choice theory $[30,38,40]$. In Malaysia, the latter is more relevant as the SOE in Malaysia is exposed to political manipulation with the State behaving as a developmentally focussed political organisation. The SOE is an instrument of intervention in the hands of politicians but is hidden from public surveillance [30]. The poor performance of State enterprises serves as a source of power in the hands of bureaucrats and managers.

In the mid-80s, the Malaysian public sector was widely criticised as inefficient. A privatisation policy was introduced in 1983 to reduce government involvement in the economy, increase the efficiency of government enterprises, and improve the government sector's finances [31,44]. While government should use SOE as instruments to achieve its social objectives (often manifested as political objectives) [5] this is not the case in Malaysia. According to Jomo, State intervention has been incorrectly identified as socialism, which supports privatisation as a measurement to restore capitalist hegemony. Statist capitalism, however, is not socialism, undermining as it does the public sector, especially public services, through privatisation; it nevertheless has important welfare implications for the people, especially public sector employees, consumers and the poor (23). It is not the issue of ownership per se which determines efficiency; it is, rather, the degree of competition. Provided there is sufficient competition, there is no discrepancy in efficiency between Stateowned or privately-owned enterprises [46,47]

In the more specific context of indigenous peoples in less developed countries, the anthropologist Michael Dove notes that, in local political realities, allegations of transnational corporations of developed countries unfairly exploiting indigenous peoples is exaggerated in comparison with exploitation by the national political-economic elites. This is because these political-economic elites are far more likely to be engaged in commercial extraction than in carrying out the public duties entrusted to them [11]. Another anthropologist Darrell Posey [11] says that less than 0.001 percent profits from drugs developed from traditional knowledge (of the indigenous peoples) have gone to the respective indigenous peoples. The profits in reality go to the national and local political-economic elites.

This paper will now examine the direct/indirect relationship between a rent-seizing State and the promotion of human rights in general and indigenous peoples' rights in particular and argue that Malaysia is a rent-seizing State and therefore the interests the small group of the political-economic elite tend to prevail over the interests of the public or society in general [18]. A proper understanding of Malaysia's status as a rent-seizing State will require an analysis of its economic policy that involves historical, social and political evaluation. This empirical analysis will demonstrate the extent to which the economic policy influences the promotion of indigenous peoples' rights in Malaysia. 


\section{The economic policy, state intervention and indigenous peoples}

Malaysia's economic policies have been mainly influenced by social and political elements within it. In the negotiation process for Malaysia's independence in 1957, the three main political parties agreed to a social contract termed "the Bargain of 1957". The explicit thrust of the social contract was the special rights for the Bumiputra (Malays and non-Malay natives) enshrined in Article 153 (31). In return, the non-Bumiputra (Chinese and Indians) were granted full citizenship. An implicit understanding among the covenants of the social contract was that the Bumiputra would have the political dominance while the nonBumiputra, especially the Chinese, would be allowed to pursue their commercial interests without hindrance. This was with the understanding that the Chinese would assist the Bumiputra to improve their economic position [13]. For unknown reasons, none of these implicit covenants of the social contract was incorporated in the Federal Constitution by Reid Commission.

\subsection{Introduction of the new economic policy (NEP)}

Despite intensified rural development efforts, industrialization policy and the establishment of SOE, by the late sixties, it was realised that the framed goal of the social contract of Bumiputra economic development through Chinese assistance had failed to materialise. As Horowitz states, it was difficult for the Chinese to give up what they perceived to be the fruit of their hard work and perseverance [19] Thus, throughout the sixties the Bumiputra remained largely marginal to the growing commercial sector while emerging business opportunities were mainly taken up by the more urbanised and commercially well-connected Chinese [27]. Widespread poverty among the Bumiputra generated resentment against the Chinese who the Bumiputra perceived to be overly benefiting from the country's growth.

The ethnic riots in 1969 after the general election marked a turning point in the country's economic policy. Closing the economic gap between the ethnic groups thus became a vital part of the development framework, the NEP was launched in 1970 as a twenty-year programme to rectify the inter-ethnic differences in economic and social development. The government set a target that within 30 years; the Bumiputra would manage and own at least 30 percent of all commercial and industrial activities, up from 2.4 percent in 1970 [25]. The NEP is aiming for national unity by reducing poverty (it fell from 49 percent in 1970 to 17 percent by 1990) and achieving inter-ethnic economic parity, especially between the politically dominant Malays and the economically well-to-do Chinese [25].

Under NEP the State has been a major actor in the economy, which has resulted in the tremendous expansion of both State intervention and the public sector. Rival ethnic demands have created leeway for the State to act independently of the class interests of civil society. Race interests have limited the State's economic choices and have accordingly shaped and reshaped policies for development [2]. New statutory bodies, State corporations, State-owned or controlled publicly listed companies as well as State-owned or controlled private companies all became the means to achieve government objectives. SOE were enjoined to involve Bumiputra in manufacturing and commerce for two reasons. First, the individual Bumiputra stood little chance of penetrating "the thicket of Chinese industrial and business networks" [50]. Second, the attempts to fund individual Bumiputra businesses in the sixties had failed mainly due to lack of business experience among the Bumiputra borrowers (49).

Economic analysis depicts the privatisation process with the NEP as a mechanism in the redistribution of the nation's wealth vis a vis the allocation of both contracts and shares 
to ethnic Malays [10, 18]. Some have argued that privatisation has simply shifted ownership from the government to Malay's political party, UMNO [37]. Critics also complain that the government has yet to be fully divested of control or ownership in any of its companies [3]. According to Jomo, for most Malaysians, the NEP has in practice now come to refer narrowly to the government's efforts to create and consolidate the Malay business and middle classes [21,27]. NEP implementation has seen the growth of the public sector, State intervention, and allegedly sanctioned ethnic discrimination, causing considerable resentment, especially among the non-Malays, and to a lesser extent among the non-Malay Bumiputra (natives in Sabah and Sarawak and Orang Asli in Peninsular Malaysia). Despite setbacks, the NEP brought about significant improvements in inter-ethnic distribution of income and wealth. Supported by figures and statistics, some scholars [12,35] conclude that the government has managed to achieve a significant decrease in poverty and inequality during the NEP period. Infrastructure, land schemes, farm subsidies, price controls and employment policies helped boost Bumiputra incomes during the period [12,35]. Some regard the implementation of NEP as having failed to develop resilient Bumiputra entrepreneurs [1].

In setting up the NEP and other economic policies, the Malaysian government may be seen as using welfare economist theory (45) as the framework for achieving national unity by reducing poverty and achieving inter-ethnic economic parity. In reality, NEP enhanced State intervention in economic development especially through SOE that primarily enriched the few with strong political connections with profitable opportunities, while the people without such connections have become increasingly vulnerable to private capitalists' power and interests (18). As Madhu Bala observed above, SOE are an instrument of intervention in the hands of politicians in Malaysia but hidden from public surveillance. Privatisation also has become an important means for enhancing the private wealth of the politically influential and well connected, and not just amongst Bumiputra. As a result, policies and laws formulated for indigenous peoples are not being implemented in a way that benefits indigenous peoples, but instead serve the interests of the State or the political-economic elites.

The NEP, which was initiated to reduce the economic disparity between the indigenous and non-indigenous peoples, has produced disparity amongst indigenous groups themselves, i.e. between the indigenous Malays and non-Malays indigenous peoples. The Malays have become the main beneficiaries of the policy while the Orang Asli who, legally speaking is not the beneficiaries of Article 153, have been neglected, together with the nonMalay natives in Sabah and Sarawak. This paper argues that, if administered properly, nonMalay indigenous peoples should receive more benefits under the NEP. In reality the minority indigenous peoples remain marginalised because the State's intervention only benefits certain groups of Bumiputra, especially Malays and the political-economic elites. State intervention evidently does not necessarily ensure economic growth [6, 17, 28, 43] for the indigenous peoples.

\subsection{Contemporary debate on NEP}

The current contemporary debate is when this economic policy, with special privileges to Malays and natives, will end. There is currently pressure, mainly from Chinese and Indians, for the policy to be abandoned and demands for complete equality [48] while the majority of Malays and natives demand that the policy be retained, as the quantitative target has not been achieved even after more than 40 years of implementation. The non-Malay demand for complete equality challenges the very heart of the Malaysian political system, the bargain of 1957, a system based upon Malay political superiority. It is a demand that challenges the source of the Malay ruling elite's power and authority [48]. 
On this issue, some have suggested that Article 153 be amended to incorporate: (i) a fixed quantitative target; (ii) a fixed schedule plan; and (iii) a fixed time limit [4]. Arguably this issue cannot be resolved by merely amending Article 153. The problem with the policy is its implementation, as discussed earlier. Even if Article 153 were to be amended to include all the variables, it will not make much difference if the government were to implement the revised law or policies in the same manner. The following statement made by Stiglitz on the Malaysian Bumiputra policy may offer some assistance in deciding on this issue:

I had the opportunity to talk to Malaysia's Prime Minister after the riots in Indonesia. His country has also experienced ethnic riots in the past. Malaysia has done a lot to prevent their recurrence, including putting in a program to promote employment to promote ethnic Malays. Mahathir knew that all gains in building a multiracial society could be lost, had he let the IMF dictate its policies to him and his country and then riots had broken out. For him, preventing a severe recession was not just a matter of economics; it was a matter of the survival of the nation [41].

If the policy were to be removed, the government would have to ensure that it put in place alternative mechanisms to prevent a recurrence of ethnic conflicts in Malaysia. Without such mechanisms, not only would the security and public order of the country be at risk but also the "survival of the nation". Despite widespread and strong opposition to the Bumiputra policy among many non-Malays, abandonment of the policy would be very threatening to the Malays and natives in Sabah and Sarawak long nurtured on the Bumiputra policy and may lead the nation to ethnic riots. It is also an undeniable fact that it has contributed to the social and political stability and harmony amongst the multi-racial and multi-faith peoples in Malaysia. Regarding the indefinite period of the special position granted to the Bumiputra, the citizenship granted to the non-Bumiputra by virtue of the Federal Constitution is also indefinite and their enjoyment of rights as Malaysians are equal to the Bumiputra. It is hard to improve on the following statement of a former Minister of Finance and President of the Malaysian Chinese Association in his appeal to Chinese to avoid challenging the Malay peoples' special positions:

The Malays are a proud and sensitive race. They are also an intelligent race, and I know that they appreciate the significance and implications of this provision (Article 153) far better than most people realize. I have no doubt in my mind whatsoever that when the time comes, the Malay themselves will ask for its abolition, but this is a matter which we must obviously leave to them to decide [20].

On the abolition of the policy, it is viewed that the policy to remain and for Article 153 to be amended to widen the scope to include the Orang Asli as the beneficiaries. The issue here is not whether the policy should be removed or otherwise but it is how the policy can be implemented to achieve the targeted objectives. The solution would be to return to the original spirit of the policy i.e. to try consciously to foster national unity by working to reduce poverty (especially among the non-Malay Bumiputra) and inter-ethnic inequalities, while minimising ethnic discrimination, especially in the political and cultural spheres. At the same time, emphasis should be placed on combating ethnic polarisation and the problems it causes in Malaysian economic development, like negative State intervention, money politics, corruption, nepotism and rent-seizing practices. 


\section{Conclusion}

This paper has demonstrated how economic policy for the indigenous people has been implemented to benefit agents of the State because of lack of accountability. On a positive note, this analysis also demonstrates that without some intervention in the form of an economic policy (NEP) to tackle the problem of income inequality, employment structure and poverty, it is unlikely that Malaysia's development experience would have been anything like as successful. However, Malaysia's mission to be fully developed in the year 2020 may not be achieved if emphasis is placed only on economic development and the institutional context of State institutions is in fact one of the determining factors. This legal inadequacy and institutional instability affect the protection of indigenous peoples. We have so far demonstrated that Malaysian economic growth has been achieved with unequal income distribution. The economic policy implemented by the government to reduce income disparity has in fact eventually caused income disparity between the Malay indigenous and non-Malay indigenous peoples.

Development or economic growth can be assessed by a measure based entirely on the economic perspective. The economic growth at issue here is not the growth or development of the economy per se, but also of the legal system, political structures, or other spheres of life. The process of economic development cannot occur at all, or is seriously inhibited, if the legal system does not function and politicians are practising rent-seizing. It is therefore crucial to study and recognise the institutional context of the State institution on which their theories and projects operate. If necessary, improvements in the structure of institutions as well as in institutional processes must be made to correct these failures. The sources for State capacity in promoting human rights should also be increased to close or eliminate the implementation gap if we are to respect the human rights of indigenous peoples in the future.

\section{Acknowledgment}

This paper is part of the research financially supported by the Universiti Kebangsaan Malaysia (UKM Young Researcher Fellowship Scheme 2012) and Ministry of Education (FRGS/2/2013/SSI10/UKM/02/4).

\section{Reference}

1. Abdul Khalid Ibrahim "Bumiputra Equity Participation in the Corporate Sector after 1990" in Bujang, Ambrin (ed.) The Malaysian Economy in Transition, INTAN, pp. 135-138 (1990)

2. J. Alamgir . JCA, 24:1, 67-80 (1994)

3. T. K. Woon, aseaeconbull , 5:3, 247-251, March (1989)

4. S.A. Baharuddin, "The NEP: The Never-Ending Polemic on the Never-Ending Policy" a paper presented at Project Amanat Negara, the office of Malaysian High Commissioner, London, 6-8 April (2007)

5. A.K. Bhattachar, "Public Enterprises - Corporate Governance and the Role of Government", Indian Institute of Management Calcutta, 10 March 2005, accessible at Social Science Research Network website at http://papers.ssrn.com/sol3/papers.cfm?abstract_id=697381.Last visited 15/09/12. 
6. R. Bhala, Trade, Development, and Social Justice, (North Carolina, Carolina Academic Press, 2003)

7. T. Bottomore, A Dictionary of Marxist Thought, (Oxford, Oxford University Press, 1987)

8. M. Bronwen, K. Yeung, An Introduction to Law and Regulation Text and Materials, (Cambridge, Cambridge University Press, 2007)

9. H.J. Chang, The Political Economy of Industrial Polic, (St. Martins Press, New York, 1994)

10. $\quad$ K. Dewenter, P. Malatesta, JOFI, 52:4, 1659-1679, Sept. (1997)

11. M. R. Dove, Center, Periphery, and Biodiversity: A Paradox of Governance and a Developmental Challenge, in S.B Brush, and D. Stabinsky, (eds.), Valuing Local Knowledge: Indigenous People and Intellectual Property Rights (Island Press, Washington DC, 1996)

12. J. H. Drabble, An Economic History of Malaysia, c. 1800-1990, (Macmillan and St Martin's Press, New York, 2000)

13. J. Faaland, J.R. Parkinson, R. Saniman, Growth and Ethnic Inequality - Malaysia's New Economic Policy, (Utusan Publications \& Distributors, Kuala Lumpur, 1990)

14. A. Gallagher, Making Human Rights Treaty Obligations a Reality: Working with New Actors and Partners 9 (Cambridge University Press: Cambridge, 2000)

15. M. Weber, H.H. Gerth, C.W. Mills, Essays in Sociology (Oxford University Press, New York, 1946)

16. M. Gillis, socres, 47:2 , 248-289 (1980)

17. M. Gillis, D. H. Perkins, M. Roemer, D. R. Snodgrass, jdih, 1:2, 8 (1996)

18. E.T. Gomez, K.S. Jomo, Malaysia's Political Economy: Politics, Patronage and Profits, (Cambridge University Press, Cambridge, 1997)

19. D.L. Horowitz, Ethnic Groups in Conflict, (University of California Pres, Berkeley, 1985)

20. S. M. Huang-Thio, malalawrevi, 6:1, 12 (1964)

21. H. Hunnum, Autonomy, Sovereignty and Self-Determination, University of Pennsylvania Press, Pennsylvania,1990)

22. B. Jessop, The Capitalist State, (Martin Robertson \& Company Ltd, Oxford, 1982)

23. K. S. Jomo, Privatisation Threatens Workers and Consumers in Jomo, K.S., p. 120 (1988)

24. K. S. Jomo, The Ascendancy of the Statist Capitalist" in A Question of Class Capital, the State, an Uneven Development in Malaya, (Oxford University Press, Oxford, 1986)

25. K. S. Jomo, Growth and Structural Change in the Malaysian Economy, (Macmillan and St. Martin's Press, New York, 1990)

26. K. S. Jomo, P. Todd, Trade Unions and the State in Peninsular Malaysia, (Oxford University Press, Oxford, 1994)

27. K. S. Jomo, Gomez, E.T, Rent and Development in Multiethnic Malaysia in Masahiko Akoi (ed.) The Role of Government in East Asian Economic Development, (Clarendon Press, Gloucestershire, 1997)

28. A. Leftwich, States of Development, (Polity Press, Cambridge, 2000)

29. M. B. Likosky, The Silicon Empire: Law, Culture and Commerce, (Ashgate, Farnham, 2005)

30. Madhu Bala, "Economic Policy and State-Owned Enterprises: Evolution Towards Privatisation in India" (2006) Indira Ghandi National Open University, accessible at Social Science Research Network website at http://papers.ssrn.com/sol3/papers.cfm?abstract_id=944423. Last visited 15/09/12.

31. M. Mohamad, The Malay Dilemma, (Federal Publications, Minnesota, 1970) 
32. R. Nordin, QLR, 3, 94-113 (2010)

33. R. Nordin, JUU, 14, 17-33 (2010)

34. J. O'Connor, The Fiscal Crisis of the State, (St. Martin's Press, New York,1973)

35. R. Rajah, I. Shari, Cambjecon, 25:1, 57-78 (2001)

36. C. Scott, Jlawsociety, 27:1, 38-60 (2000)

37. M. Scott, Where the Quota is King, New York Times, November 17, p. 63 (1991)

38. W. G. Shepherd, Public Enterprises: Economic Analysis of Theories and Practice, (Lexington Books, Maryland, 1976)

49. Speech by Nor Mohamed Yakcop, Finance Minister, accessible on Malaysian Treasury website. Last visited 15/09/12.

40. P. Starr, Yalelawpolirevi, 6:1 , 6-41 (1988)

41. J. E. Stiglitz, Globalization and Its Discontents, (W.W. Norton and Company, New York, 2002)

42. P. M. Sweezy, Theory of Capitalist Development, Indian Edition, (K.P. Bagchi and Co, west Bengal, 2001)

43. M. P. Todaro, Economic Development $6^{\text {th }}$ ed., (Addison-Wesley, Boston, 1996)

44. D. Tsuruoka, FEER, 42-46, 20 December (1990)

45. Weiss, The Myth of the Powerless State: Governing the Economy in a Global Era, (Polity Press, Cambridge, 1998)

46. O. E. Williamson, "Corporate Control and the Theory of the Firm" in Manne, H., (ed.) Economic Policy and the Regulation of Corporate Securities, (American Enterprise Institute, Washington, DC, 1969)

47. Williamson, O.E., Corporate Control and Business Behaviour: An Inquiry into the Effects of Organisational Form on Enterprise Behaviour, (Englewood Cliffs, N.J: Prentice Hall, New Jersey, 1970)

48. M. A. Wu, R. H. Hickling, Hickling's Malaysian Public Law, (Selangor Darul Ehsan, Malaysia : Longman, 2003)

49. J. V. Jesudason, Ethnicity and the Economy - The State, Chinese Business, and Multinationals in Malaysia, (Oxford University Press, Oxford, 1989)

50. Z. A. Yusof, Breeding Entrepreneurs and Enterprise through the New Economic Policy - A Review, MIER Discussion Papers No 23, Kuala Lumpur (1989) 